\title{
Implications of postmodern thinking on Chinese Language and Literature Teaching
}

\author{
Yan Li \\ Linyi University Feixian College \\ Shandong,273400 China
}

\begin{abstract}
With the continuous deepening of China's reform of higher education, post-modern educational be thought as a new educational theories, it has a great reference on teaching Chinese language and literature, opened up a new path for teaching Chinese language and literature. Postmodern Education has challenged the traditional educational thoughts in the teaching ideas of equality, dialogue teaching methods, interpretation pedagogy, teaching evaluation, its specialty lays on the reference it puts on teacher reform and innovation in the teaching of Chinese language and literature. Based on this, this thesis discusses how to conduct Chinese language and literature teaching in the post-modern thinking.
\end{abstract}

Keywords- Postmodern thinking education, higher education, the teaching of Chinese language and literature

\section{OVERVIEW OF POSTMODERN EDUCATIONAL THOUGHTS}

In many contemporary educational philosophy theories, postmodern teaching thoughts occupies an important position, it is not only a more profound critique of the traditional mode of education, but also opened up new educational development ideas.

\section{A. Decentralized and equal teaching ideas}

Post-modern educational thought breaks the traditional teacher-centered educational thinking in the curriculum and teachers level, puts strong emphasis on the decentralized and equal teaching philosophy, which is opposed to the control of teaching of teachers, in opposition to regard teachers and knowledge as the central idea, promote equality between teachers teaching and encourage building interactive relationships. Post-modern educational thoughts redefine the role of the teacher of the position and role in the teaching process, it includes the teaching philosophy of equality and democracy, as the American teaching and research experts pointed out that the teacher is not the external dictator, but should be leading part of the inherent teaching scenarios.

\section{B. Dialogue teaching methods}

Dialogue is the core of the modern educational thoughts; it starts from the understanding of the teaching process that is, emphasizing the construction of dialogue relations which have characteristics like the openness, equality, creativity, rich pluralistic values teachers in the teaching process. Japanese scholars pointed out: practice in learning is dialogue in learning. Advocate dialogue in teaching is to promote a teaching atmosphere of mutual respect; mutual understanding of the students and teachers, is encouraging teachers to respect students' individual differences in order to carry out teaching concepts of equality, to embody individualized teaching thinking.

\section{Hermeneutic teaching methods}

Hermeneutic teaching methods are advocated by postmodern educational thoughts, it is different from traditional pedagogy and teaching style about promoting teaching, but stressed the premise of accepting teacher education, with optimism, happy state of mind to expand learning path of truth and then to guide students into the scene of truth. The advantages of dogmatic interpretation of the traditional teaching method are used in the post-modern teaching process, and the disadvantages are thrown away, thus students learn to interpret their own life experiences and cultural backgrounds in teaching text, this teaching method fully reflects the creativity of teaching and learning, but also stressed students' imagination.

\section{Autobiographical teaching evaluation}

Post-modern educational thoughts thought that there are individual differences; teachers can not use a uniform yardstick to measure each student's learning level. Teaching evaluation should emphasize the complexity of the evaluation criteria, dynamic and ambiguity, see the students as the discoverer and explorer of knowledge, oppose to standardized evaluation methods tests. As noted by Peine, teaching evaluation committee should be parents, community leaders, teachers and other students together, they together give evaluations.

\section{CHINESE MODERN LiTERATURE TEACHING PROBLEMS AND DILEMMAS}

\section{A. A huge impact of times change on students}

With the rapid development of economy and people's desire for ever-expanding substances, literary education encountered unprecedented difficulties in the commercialization of social environment. The brunt of all is the changes of students in the pursuit of spirit and appearance. More and more students are no longer put the self-enrichment, expansion of their life and the deepening 
self-awareness and experience on the first place, but very realistically seem university education the means to survive and seek material benefits. Thus, gradually literature class eclipsed when facing a variety of certificates which have employment effects, students gradually lose enthusiasm in modern literature class, they greatly care about the computer, English certificates, and do not want to take the time to clarify the literary trends, analyze literary phenomenon, read literature, modern literature to understand the profound ideological thoughts and unique artistic charm of great persons. As scholar Li Yi pointed out: challenges to teaching, in addition to the reasons for the current education system, where considerable force comes from the Chinese Modern Literature basic recipient of this course - the majority of the young students, we should say this power is very disturbing, because the resistance from recipients is from resistance from the future, obstruction in the future is the most terrible.

\section{B. Reform of university education, make teaching space increasingly narrow in Modern Chinese Literature}

This is mainly reflected on the reduction of the number of hours of teaching and the stretched feeling it has brought. Most colleges and universities are now confronted with the expertise education to general education transformation, followed by reconstruction and integration of curriculum system and teaching content. Under this guiding ideology, Chinese professional disciplines in the past and tradition gradually be broken up, a large interdisciplinary basic course has increased, while the students time is limited, the result is modern literature class time is compressed to two-thirds of the original, even half. Therefore, in the teaching process, when facing complicated literary clues, countless writers and masterpiece, teachers are often do not know how to take into account both the literary history of the clues, the works of writers and literary phenomenon analysis. Thus, even the most prestigious modern literature writers such as Lao She, Shen Congwen, $\mathrm{Ba}$ Jin, $\mathrm{Cao} \mathrm{Yu}$, hours of learning arrangement is quite limited; while other well-known writers such as Xiao Hong, Fei Ming, Lin Qian, Shiying, Li Jieren, etc. often only make a brief introduction. Such modern literature class has changed into modern literature, students only receive the superficial knowledge, and don't understand the theories totally, and the clues are so vague that they can not analyze literary phenomenon, and lack of perceptions of writers and their works

\section{Conflict of dual identity of modern literature teacher}

Wen Rumin has pointed out: the origins of modern Chinese literature and university education are closely related, nine out of ten employees are teachers, which should highlight the main industry of its growing status of teaching. However, in the university teacher's job classification, we regard research as a fixed target linked to teachers job promotion, pay attention to writing academic monographs and papers in the case, but put few focus on teaching effectiveness study of teachers, teaching and research are not properly emphasized. In modern literature for teaching activities, what to teach, how to teach, if it is effective? These important issues, was quite ignored by a lot of modern literature teachers, worse, some teachers just deal with the task of teaching and class casually. So we see that in the teaching of modern Chinese literature, the immutable still is centered on teachers and teaching materials, three-steps teaching (the writer's life and social background, the contents of the work, artistic features) flooded the classroom, teachers are addicted to chalk and talk of lectures, the teaching methods are restrained into informative and receptive teaching. Students are increasingly dependent on teachers to teach so it develop into a habit, and no longer bear active learning enthusiasm, don't thinking independently and take initiative, so the theory is a hallow one, they have a small amount of extra-curricular reading, and then have tunnel vision, so weak writing ability is inevitable. So students not only have no solid professional foundation, but also lack of independent thinking, and the ability to explore and the innovative courage.

\section{IMPLICATIONS OF POSTMODERNISM ON CHINESE} LANGUAGE AND LITERATURE TEACHING MODE AND METHOD

Postmodernism, as a new educational philosophy and theory, its rational core are regarded as the basic concept, and which has been internalized in most people's idea. Slattery described the three aspects of postmodern curriculum development: choice of textbooks, building learning experiences, assessment of learning tasks, emphasis on research on learning experience, focusing on practice, identified three basic characteristics of postmodern curriculum practice: cooperation, the whole process perspective, interdisciplinary and multi-level courses. So in the teaching application of Chinese language and literature, postmodernism has inspiration to us as follows: openness and interaction concept. Based on openness, in teaching practice of postmodern curriculum, we emphasize interaction, and that interaction is the core value of the theory of modern educational practical theories. Modern educators Rorty further explained the theory of dialogue, making conversation become the core of the modern teaching. Dialogue theory requires interlocutor be equal, open, creative, with diverse values. Our pedagogic researcher Zhong Qiquan quoted Japanese scholars' saying in "Dialogue of international vision and local action": learning can be likened to the unknown from the known world. In this journey, we encounter new world, meet new ones, have new selfencounter; in this learning process, we communicate with the new world, have a new dialogue with others and the new self. Therefore, the practice of learning is the practice of dialogue. Inherent spontaneity and Equality is based on the understanding of cognitive learning process, postmodernism emphasizes equality in the teaching process. In traditional teaching, the teacher is sacred and is the indisputable knowledge transmitters, and students are passive recipients of knowledge. The Dole believes in teaching should decentralize; teachers and students are active participants in learning, prompting the body to learn to take the initiative to explore, in order to achieve both teaching and learning. In addition, Dole also think the real authority and control is develop inherently, rather than external, and it generates in the dialogue when teachers and students are equal in 
teaching situation, not established in brutal way laterally. An equal relationship, communication between teachers and students is two-way, interactive, and be flexible and creative. The diversity and methods: in the choice of teaching methods of teaching practice reflects the diversity of cognitive, post-modernism think that the choice of teaching methods should not be a single, rigid one; rather appropriate object should select the appropriate method to achieve the appropriate scenario proper purpose. Postmodernism is more emphasizing on the interpretation of pedagogy, not only by teachers to teach, but put more emphasis on adjusting its attitude, and the students' creative thinking exercise. And the evaluation concept and regression is based on the regression, Dole stressed the importance of teaching evaluation in teaching practice. Teaching evaluation is not only for student learning assessment, it should be reflected in the teaching methods and the effect of feedback. Through this feedback, to continually reflect on and improve teaching methods and course content, in order to better promote the improvement of teaching effectiveness, thus forming a good loop. Meanwhile, the evaluation of the concept of knowledge centers should shift attention to themselves, from the memories of knowledge, understanding, and judgment, comprehensive and simple application to objective evaluation of human development.

In summary, the application of modern educational thought, teaching Chinese language and literature can take place from these perspective: the teacher-student relationship can take equal dialogue attitude; on teaching methods, interactive measures be taken to avoid single discourse; the curriculum, according to the scientific method of implementation, there is advance plan and communication before class, and adjustment and choice in the class; feedback afterschool on the mutual evaluation, continuous improvement, then form a complete teaching and learning cycle.

\section{SIGNIFICANCE OF POST-MODERN EDUCATIONAL THOUGHTS ON CHINESE MODERN LITERATURE TEACHING}

Since the late 20th century, the rapid transformation of society, the rapid development of commodity economy, brought changes and values of society and a whole ideological confusion, shrinking the influence of literature, brought no small crises and challenges to our modern literature teaching has. The traditional teaching of students has increasingly shown its limitations in the culture of thinking, learning initiative to mobilize peers and, can not adapt to the reform and development of university teaching. Post-modernism educational theories break the shackles of tradition, innovate educational thinking ways, establish educational pluralism of ideas, updating teaching philosophy and teaching behavior of teachers, with full attention to students' individual differences, and really practice the education tenets: for all students, all for students, for students' all, to teach students to learn, live and even know the life of the spirit, and not just how to make a living skills, then achieve the ultimate goal of education. Yeats said, the world's literature is the most important spiritual force in my mind, the creator of all highest values, this power is not only recognized in sacred books which recognized by everyone, and show every imagination through sincere songs full of strength and power, stories and drama. In the history of Chinese modern literature from the traditional to modern, the cohesion reflects in the modern spiritual pursuit and emotions, so it has similar emotions with the current demands of the Chinese people's thoughts and feelings, awareness and understanding of modern literature, in a way is the awareness and understanding of contemporary Chinese people themselves. It is in this sense that modern Chinese literature has its own unique value and charm, has its own irreplaceable role. This is true, although modern Chinese literature and confronted with new problems and challenges the times presented, but also is an opportunity for selfreflection and progress. Post-modernism educational thoughts innovate by its educational philosophy and ways of thinking and provide valuable and meaningful reference for the teaching reform of our modern literature.

\section{REFERENCES}

[1] Li Zhiqin. How to carry out post-modern educational thought Chinese Language and Literature Teaching [J]. Modern Reading (Education Edition), 2013,21:6.

[2] Shi Hui. After Chinese Language and Literature Teaching. Theory of modern education under the idea of $[\mathrm{J}]$. Education Forum,2011,15:132-133.

[3] Zhao Ying. After Probe how modern educational thinking to Chinese Language and Literature Teaching $[\mathrm{J}]$. Chinese school education, 2011,22:83.

[4] Fu Qingquan. Implications of Modern Educational Thought on the Teaching of Modern Chinese Literature [J]. Yangtze Normal University,2012,06:86 -89+140.

[5] Pan JiaMing.Teaching of Chinese Language and Literature Teaching in the Perspective of Postmodern [J]. Jianghan University (Social Sciences Edition),2009,01:100-103.

[6] Lan XianFa. Study Chinese language and literature teaching in postmodern educational thought background $[\mathrm{J}]$. Group text world, 2012,24:173.

[7] Wengwei Mei. Based on the ideas of modern Chinese literature after teaching innovations Discussion [J]. Forum,2013,02:57-58 education.

[8] Yang Zhou. Revelation composition of Chinese language and literature teaching in primary education professional writing $\begin{array}{llll}\text { curriculum } & \text { reform } & \mathrm{J}] \text {. } & \text { LANGUAGE }\end{array}$ LITERATURE,2012,07:164-165 